\title{
USAGE OF CRASH HELMET AMONG COMMERCIAL MOTORCYCLISTS IN ILORIN, NIGERIA
}

\author{
Bolaji Abdulkadir USMAN* \\ Department of Geography and Environmental Management, Faculty of Social Sciences, University of Ilorin, \\ Ilorin, Nigeria, e-mail: usman.ba@unilorin.edu.ng
}

\section{Olalekan Moshood ABDULKADIR}

Department of Geography and Environmental Management, Faculty of Social Sciences, University of Ilorin, Ilorin, Nigeria, e-mail: abdulkadirmoshood49@gmail.com

Citation: Usman, B. A., \& Abdulkadir, O. M. (2019). Usage of Crash Helmet Among Commercial Motorcyclists in Ilorin, Nigeria. Analele Universităţii din Oradea, Seria Geografie, 29(2), 86-95. https://doi.org/10.30892/auog.292109-803

\begin{abstract}
This study examined usage of helmet among commercial motorcyclists in Ilorin, Nigeria. Simple random sampling was used to select 120 motorcyclists, who were surveyed with a structured questionnaire. Descriptive statistics, including percentages and mean scores were used to analyse the data. Results showed that only $14.2 \%$ of the riders fully abide with the helmet law. High mean scores of 3.81 and 3.32 for 'helmet usage is important' and 'helmet prevents head injury' respectively, however showed that most riders are aware of the protective role of crash helmets. It is recommended that there should be stricter enforcement of the helmet law.
\end{abstract}

Key words: Commercial motorcycle, crash helmet, road safety, public transport

$$
* \quad * \quad * \quad * \quad * \quad *
$$

\section{INTRODUCTION}

Unprotected road users such as pedestrians, pedal cyclists and motorcyclists constitute the most vulnerable group on the road because they are directly exposed to injury from road crashes. For instance, in some cities of the developing world up to $80 \%$ of road fatalities may relate to this group of road users (Gbadamosi, 2006; Global Road Safety Partnership, 2014). Motorcyclists in particular are known to have poor safety records and most motorcycle accidents are usually fatal. For example, in the United Kingdom the mortality rate for motorcyclists is twice that of pedal cyclists and more than 16 times for car occupants (Department of Environment, Transport and the Regions - DETR, 2000). The US National Highway Traffic Administration (2002) also classified motorcycles as the most dangerous vehicles to drive. Similarly, $70 \%$ of road fatalities in Thailand involve motorcyclists (Global Road Safety Partnership, 2014). 
The emergence of motorcycles as means of public transport in Nigeria was encouraged by the high cost and shortage of transport services, such that supply could not match the demand for transport services in both urban and rural areas (Olubomehin, 2012). Motorcycles have become widespread as means of transportation because of their high manoeuvrability which is a great advantage in heavy traffic (Olakulehin et al., 2015), ability to pass along narrow paths and relatively affordable costs as compared to motor vehicles. As rightly observed by Ogunrinola (2011) motorcycles have become indispensable for transporting people and their goods and also serve as source of employment for large number of people in the country. However, despite its positive contributions, commercial motorcycle operation is known to have many negative effects in the country. For instance, apart from significantly contributing to the increasing trend of road traffic accidents, commercial motorcycle operation is known to negatively affect agriculture by attracting labour from farming. In addition, due to their high manoeuvrability motorcycles are increasingly being used to perpetrate criminal activities like armed robbery, assassinations and other heinous crimes in the country (Falope, 1991; Olubomehin, 2012; Adefalu et al., 2013).

The rate of road traffic accidents has increased with the introduction and spread of motorcycles as means of public transportation in Nigeria. For example, motorcycles alone accounted for $31 \%$ of road traffic accidents in the country from 2000 to 2005, while cars, luxury buses, mini buses and vans jointly contributed 52\%. Trailers, tippers and articulated vehicles contributed $17 \%$ to road crashes during the same period. It has been estimated that the chances are 8:10 that a motorcycle accident will result in death or serious injury (Federal Road Safety Commission - FRSC, 1989; Gbadamosi, 2006; Olusayo et al., 2015). Increasing trend of involvement of motorcyclists in road crashes in Nigeria has been attributed to the uncoordinated mode of operation and low level of compliance with road safety regulations (Gbadamosi, 2006; Tunde et al., 2012). The high rate of use of intoxicants as performance enhancers among commercial motorcyclists is also seen as a contributory factor to the high trend of their involvement in road crashes in the country (Adisa, 2010). Motorcyclists who are high on drugs or other forms of intoxicants are not likely to observe traffic rules, are more likely to engage in risky behaviour, disobey road signals and less likely to protect themselves with crash helmets (Branas and Knudson, 2001; Adisa, 2010; Johnson and Adebayo, 2011). Some scholars have also identified the role of what has been termed "road traffic immune delusion syndrome". This is when drivers believe in the efficacy of charms or some supernatural power to protect them from injuries or death in case of accident (Iweze, 2011; Olusayo et al., 2015).

The use of crash helmet is known to significantly reduce fatalities among motorcycle operators and passengers. For instance, the US Centre for Disease Control and Prevention (2009) noted that helmet use prevented as much as $37 \%$ fatalities among motorcycle operators and $41 \%$ of fatalities among passengers. In 2010 alone, helmet use saved the lives of 1,544 American motorcyclists, and an additional 709 lives might have been saved if all motorcyclists had worn helmets. Motorcyclists with no helmets were also found to be over three times more likely to suffer brain injury compared to those who wear helmet (The United State National Highway Traffic Safety Administration / NHTSA, 2012). Higher incidence of head and cervical injuries and mortality in unhelmet patients compared to helmeted ones have also been observed in Nigeria (Solagberu et al., 2006). According to the FRSC (1989) most fatalities among motorcyclists are due to head injuries which could have been prevented if motorcyclists were wearing crash helmets.

Some factors have however been found to be responsible for non-usage of helmet among motorcyclists in various parts of the world. These include the notion that helmet usage increases rather than decreases the risk of an injury by reducing field of vision and creation of discomfort (Dandona, 2005). Others are inconvenience of removing helmet in order to receive phone calls, problem of storage to prevent being stolen when not in use and inconvenience of wearing helmet in hot weather (Dandona, 2005; WHO, 2006; Solagberu et al., 2006). Rate of helmet usage has however been found to rise with increasing level of education (Swaddiwudhipong et al., 1998) and age of riders (Hung et al., 2006; Ackaah and Afukaar, 2010). 
Various studies in Nigeria have indicated that compliance with road safety regulations including wearing of crash helmet by commercial motorcyclists is low (Adisa, 2010; Johnson and Adebayo, 2011; Tunde et al., 2012; Olusayo et al., 2015; Oyelade et al., 2015). For instance, it is common occurrence to find both the rider and the passenger riding without crash helmets. Oni et al., (2011) noted that in Lagos State, only $12.4 \%$ of motorcyclists made use of crash helmet. Relatedly, in a study in Ogbomoso, Oyo State, Oyelade et al. (2015) found that while the rate of use of helmet among commercial motorcyclists was generally low, married riders more regularly use helmets compared to unmarried riders. A study on Ilorin city by Yusuf et al., (2014) found that only $5.8 \%$ of motorcyclist who sustained head injury wore helmet at the time of crash. While over $70 \%$ of those affected falls within the economically active age group of 15-44 years, brain injury, skull fracture and associated injuries to the face were found to be very common among the victims. They concluded that many of these injuries might have been prevented or the severity reduced if the riders were wearing crash helmets.

While road traffic/safety officials have continued to struggle to enforce the use of helmet among motorcycle riders, presently it has become impossible to enforce its use on their passengers. Motorcycle passengers have refused to use helmets (which are expected to be provided by the operators) due to fear of catching skin diseases or coming under black magic spell. People fear being infected with infections like scabies and ring worms among others. It is also common belief that helmets could be laced with black magic spells that could make the wearer unconscious so that they could be easily robbed (Oboh, 2009) or even kidnapped for ritual purposes.

The high rate of involvement of commercial motorcyclists in road accidents and various forms of criminal activities have resulted in the outright ban or restriction of their operations in some cities across the country. Even the National Council of Transport in its 2014 national conference called for the proscription of commercial motorcycles nationwide to reduce accidents and ensure safety on Nigerian roads. The Council further called for the adoption of safer and more efficient transport systems in the country (Blueprint Newspapers Online, 2014). While also making reference to the poor attitude of commercial motorcycle operators to traffic rules and regulations and their high rate of involvement in road crashes, the Kwara State command of the FRSC stressed its support for the proposed proscription of their operations averring that such ban would reduce crashes on the roads (Ilorin.Info, 2017). However, the Federal Government has opposed the banning of commercial motorcycles because of the negative effects such ban may have on the economy. For instance, while noting their vital role in the economy in terms of creation of employment and provision of cheap transportation services, the Minister of Transport, Rotimi Ameachi suggested the introduction of training programmes for the operators to improve their adherence to road safety regulations (The Eagle Online, 2017). Consequently, in view of these important contributions of commercial motorcycles to the economy, many states such as Kwara State have resisted the temptation of proscribing or even restricting their operations. Therefore, in spite of its poor safety record this mode of transportation has remained as an important means of public transport in Ilorin city. While previous studies have also examined the usage of crash helmet among motorcyclists in other parts of the country (Oyelade et al., 2015; Olakulehin et al., 2015) this study examined the usage of crash helmet among commercial motorcyclists in Ilorin city. The study is limited to only the operators (riders) because there is no enforcement on usage by passengers. It specifically focuses on the prevalence of helmet use among the operators and the level of awareness of the motorcyclists on the benefits of using crash helmet.

\section{MATERIALS AND METHODS}

The study was conducted in Ilorin the Kwara State capital. It lies on the geographical coordinates of latitude $8^{\circ} 3^{\prime} \mathrm{N}$ and longitude $4^{\circ} 33^{\prime} \mathrm{E}$ in the North Central region of Nigeria. The city covers an area of about $100 \mathrm{~km}$ square (Kwara state Diary, 1997; Usman and Akinola, 2017). Ilorin metropolis consists of 26 political wards based on Independent National Electoral 
Commission's (INEC) (2010) delineation of wards. These political wards are spread across parts of three Local Government Areas (Ilorin East, Ilorin West and Ilorin South). Twelve (50\%) political wards were chosen for the study using simple random sampling technique, through ballot. The selected wards are Baboko, Gambari I, Akanbi IV, Balogun Fulani II, Adewole, Zango, Ogidi, Magaji Ngeri, Okaka II, Alanamu Central and Oke-Ogun wards. One motorcycle park was then chosen from each of the wards through simple random sampling, giving a total of twelve motorcycle parks (figure 1).

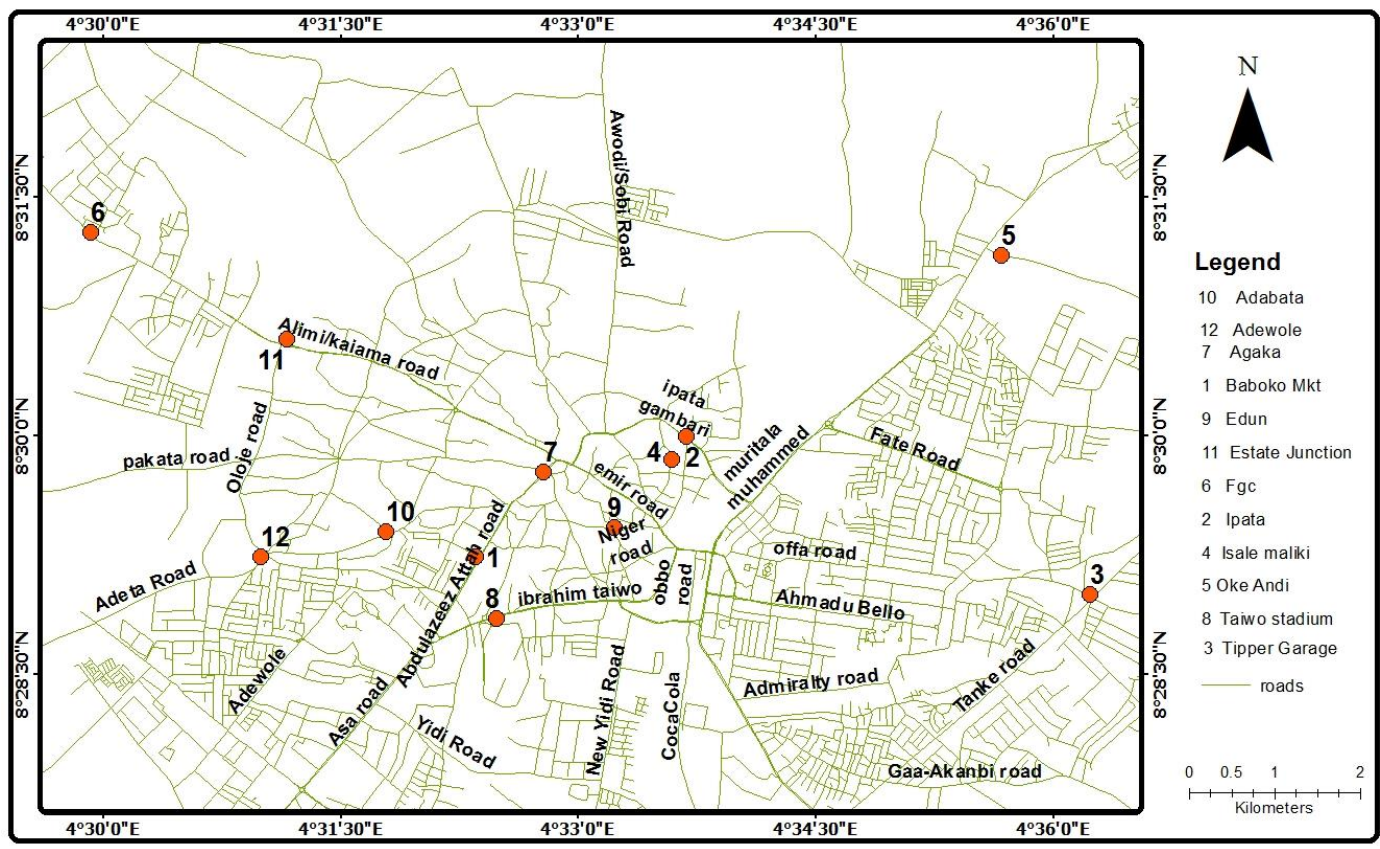

Figure 1. Map of Ilorin city showing the sampled motorcycle parks Source: Adapted from Kwara State Ministry of Lands and Housing, 2013

Ten registered motorcyclists were then sampled from each of the twelve parks giving a total of 120 motorcyclists. The survey was conducted at the parks using a structured questionnaire. The sampled motorcyclists were chosen based on their willingness to participate in the study. Descriptive statistics including frequency distribution, percentages and mean scores were used to analyse the data.

\section{RESULTS AND DISCUSSION}

\section{Socio-Economic Characteristics of the Respondents}

All the respondents were found to be males and majority (71.9\%) fall within the highly productive age group of 18-40 years (table 1). This is in line with the result of many other studies that commercial motorcycle operators mostly fall within the economically active population (Adisa, 2010; Tunde et al., 2012; Yusuf et al., 2014). The results further show that as high as $74.2 \%$ of the respondents have some formal education although, $33.3 \%$ of them did not go beyond primary school. The high proportion of the educated among the motorcyclists is not surprising because unemployment has been attributed to be a major factor pushing the youth into commercial motorcycle operation in the country (Ogunrinola, 2011). Table 1 also shows that $46.9 \%$ of the respondents earned above 20,000 Naira (\$64.1) per month out of whom $8.3 \%$ earned above $\mathrm{N} 40,000(\$ 128.2)$ per month. It is also evident from the results that commercial motorcycle 
operation is a very important source of income particularly noting the fact that the minimum wage in the country is just $\mathrm{N} 18,000(\$ 57.7)$ per month. It is therefore expected that the occupation will continue to attract more economically active members of the society if the present high level of unemployment put at $18.8 \%$ (National Bureau of Statistics / NBS, 2018) persists.

Table 1. Socio-Economic characteristics of the respondents

(Source: Field Survey, 2017)

\begin{tabular}{|c|c|c|}
\hline \multicolumn{3}{|l|}{ Age } \\
\hline Respondents & Frequency & $\%$ \\
\hline $18-30$ & 47 & 39.2 \\
\hline $31-40$ & 38 & 31.7 \\
\hline $41-50$ & 27 & 22.5 \\
\hline $50-60$ & 8 & 6.7 \\
\hline Total & 120 & 100.0 \\
\hline \multicolumn{3}{|l|}{ Marital Status } \\
\hline Single & 61 & 50.8 \\
\hline Married & 59 & 49.2 \\
\hline \multicolumn{3}{|l|}{ Level of Education } \\
\hline No formal & 31 & 25.8 \\
\hline Primary & 40 & 33.3 \\
\hline Secondary & 34 & 28.3 \\
\hline Tertiary & 15 & 12.5 \\
\hline \multicolumn{3}{|l|}{ Monthly Income ** } \\
\hline$<\$ 10,000(\$ 32.06)$ & 13 & 10.8 \\
\hline$\$ 10,001-\$ 20,000$ & 52 & 43.3 \\
\hline$\$ 20,001-\$ 30,000$ & 23 & 19.2 \\
\hline$\$ 30,001-\$ 40,000$ & 22 & 18.3 \\
\hline Above $\$ 40,000$ & 10 & 8.3 \\
\hline \multicolumn{3}{|c|}{ Number of years in Business } \\
\hline Less down 2years & 19 & 15.8 \\
\hline 2-4years & 44 & 36.7 \\
\hline 5-6years & 27 & 22.5 \\
\hline 7-8years & 19 & 15.8 \\
\hline Above 8years & 11 & 9.2 \\
\hline \multicolumn{3}{|c|}{ Motorcycle Ownership } \\
\hline Owned by rider & 110 & 91.7 \\
\hline Not owned by rider & 10 & 8.3 \\
\hline \multicolumn{3}{|c|}{ Other Vocational Activities } \\
\hline Yes & 69 & 57.5 \\
\hline No & 51 & 42.5 \\
\hline
\end{tabular}

** Note: exchange rate at $\$ 311.9$ to US $\$ 1$ as at the time of survey in July, 2017 
Table 1 further show that a large majority (74.2\%) of the respondents have more than two years riding experience, while $9.2 \%$ have been in the business for more than eight years. Furthermore $57.5 \%$ of the motorcyclists have some vocational training but have abandon such occupation for commercial motorcycling because it yields better financial returns. The implication is that farming and many other occupations such as motor mechanical works, electrical works, bricklaying and carpentry have been losing trained labour to commercial motorcycle operation in the country with great negative repercussions for the economy.

\section{Prevalence of Crash Helmet Usage among Commercial Motorcyclists in Ilorin}

In order to establish the rate of adoption of crash helmet among the motorcyclists, the regularity of use, reasons for usage or non-usage and respondents' opinion on whether the use of helmet should be made optional where examined. Results show that most $(81.6 \%)$ of the commercial motorcyclists possess crash helmet (table 2). It was however discovered that the high rate of ownership of crash helmet does not indicate adherence to the helmet law by the riders. Examination of the frequency of usage of helmet showed that $15 \%$ of the respondents agreed that they only wear head helmet on rare occasions. However, $45.8 \%$ of the respondents used helmet most of the time.

Table 2. Prevalence of crash helmet usage among the riders (Source: Field Survey, 2017)

\begin{tabular}{|l|l|l|}
\hline Variables & Frequency & $\%$ \\
\hline Possession of helmet & & \\
\hline Yes & 98 & 81.6 \\
\hline No & 22 & 18.4 \\
\hline Total & 120 & 100 \\
\hline Frequency of helmet use & & \\
\hline Rarely & 18 & 15.0 \\
\hline Sometimes & 30 & 25.0 \\
\hline Most of the time & 55 & 45.8 \\
\hline Always & 17 & 14.2 \\
\hline Main reason for helmet usage & & \\
\hline It is just a habit & 21 & 17.5 \\
\hline To obey the law & 29 & 24.2 \\
\hline To avoid being fined/punished & 51 & 42.5 \\
\hline Because of its safety implications & 19 & 15.8 \\
\hline
\end{tabular}

As also seen in table 2, only $14.2 \%$ of the respondents put on helmet at all times when riding their motorcycles. Since crash helmets are supposed to be used at all times when motorcycles are being operated, it could be seen that adherence to this traffic regulation is very low. In a situation where only $14.2 \%$ fully abide by this regulation, it implies that there is still a long way to go in terms of enforcing this regulation in the area. This result is in line with the findings of some other previous studies that have also shown that rate of adherence to the helmet law is low among motorcyclists in Nigeria (Olakulehin et al., 2015; Oyelade et al., 2015). Furthermore, it is common practice among commercial motorcyclists in the area, to put on helmet only when police or other traffic officials are sighted and the helmet is immediately removed again when the officers are out of sight. For those who do not possess helmet at all it is usual for such riders to completely avoid routes where they are likely to come across traffic officials (figures 2 and 3 ). 


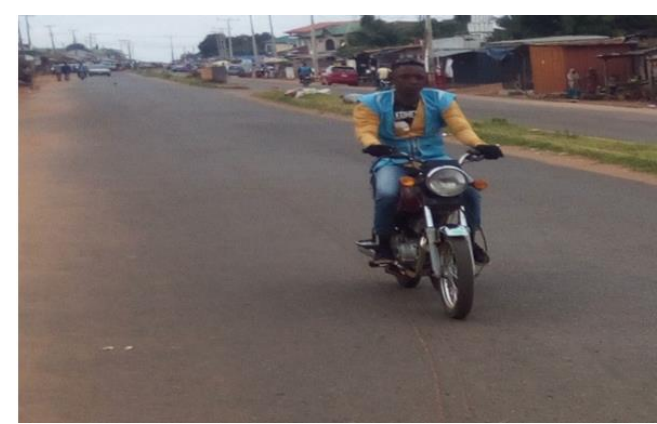

Figure 2. A Commercial motorcyclist without helmet in Ilorin

Source: Authors, 2017

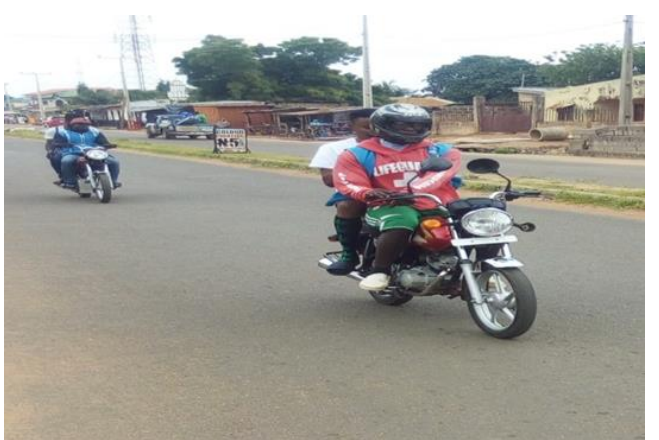

Figure 3. Helmeted motorcyclists with unhelmet passengers

Source: Authors, 2017

\section{Reasons for the Use of Helmet by Commercial Motorcyclists in Ilorin}

In order to better understand the factors influencing adherence to the helmet law among the motorcyclists, the study also examined their main reasons for the use of crash helmet. The results show that a significant proportion (42.5\%) of the motorcyclist's wear helmet in order to avoid facing the wrath of the law in form of fines or even imprisonment (table 2). Another $24.2 \%$ do so just to obey the law without really being interested in why its usage is important. Table 2 further shows that only $15.8 \%$ of the motorcyclists use helmet because of its safety implications and that it may save them from serious injuries or even death in case of accident. This implies that most of the riders are not mindful the safety benefits of crash helmet; rather they see it is a burden that must be borne to avoid altercation with the law. Such is the situation that cases have been recorded of motorcyclists who wear painted dried shells of pumpkin fruits (calabash), pots and pans as helmet to beat the law (Oboh, 2009). Many others obtain inferior plastic helmets that would break into pieces on impact when crashes occur. This shows that most of the motorcyclists do not attach much importance to the wearing of crash helmet, which justifies the need for proper enlightenment to change the orientation of the riders.

\section{Commercial Motorcyclists' Opinion on Enforcement of Helmet Use}

A major proportion (90\%) of the riders wants the use of crash helmet to be made optional rather than being compulsory. Among this group, $75.8 \%$ are strongly in support of its being made optional as shown in table 3.

Table 3. Respondents' opinion on enforcement of helmet use

(Source: Field Survey, 2017)

\begin{tabular}{|l|l|l|}
\hline $\begin{array}{l}\text { Whether helmet use be made } \\
\text { optional }\end{array}$ & Frequency & Percent \\
\hline Strongly agree & 91 & 75.8 \\
\hline Agree & 17 & 14.2 \\
\hline Disagree & 07 & 5.8 \\
\hline Strongly disagree & 05 & 4.2 \\
\hline Total & 120 & 100 \\
\hline
\end{tabular}

It implies that most of the riders view the regulation on use of crash helmet as an unnecessary imposition. This is not surprising because public apathy to traffic safety regulations is a common phenomenon in the country (Gbadamosi, 2006; Tunde et al., 2012). For instance, many 
motorists in Nigeria view traffic regulations such as the use of seat belt and avoidance of use of cell phones while driving among others as unnecessary. Some even believe that all accidents and the results of such accidents are ordained to happen, so preventive actions cannot change what will happen. Evidence therefore abounds about people who believe in the efficacy of charms or some supernatural power that would protect them in case of accident (Iweze, 2011; Olusayo, et al., 2015). For example, Olusayo et al., 2015 found that many commercial motorcyclists in Ogbomoso, Oyo State Nigeria, believed that they are immune to road traffic injury by relying on the efficacy of prayers or charms.

\section{Awareness of the Importance of Crash Helmet among the Riders}

The level of awareness of the motorcyclists on the importance of crash helmet was also examined. This was done by rating their views on the role of crash helmet in preventing head injury, the need to continue enforcement of helmet use, whether the use of helmet is necessary and whether non-use of helmet should attract greater penalty. As shown in table 4, majority (62\%) of the motorcyclists agreed that helmet can prevent head injury though only $8.3 \%$ strongly agreed with this view. However, $60.9 \%$ of the riders are against the enforcement of helmet usage while only $8.3 \%$ of the operators believe that breaking of the helmet law should attract greater penalty. Table 4 further show that only $37.5 \%$ of the riders agreed that helmet should always be worn while riding.

Table 4. Level of awareness of the riders on the importance of crash helmet

(Source: Field Survey, 2017)

\begin{tabular}{|c|c|c|c|c|c|c|c|c|}
\hline Variables & 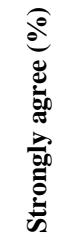 & 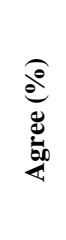 & 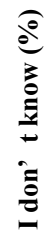 & 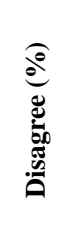 & 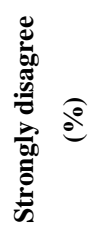 & $\frac{0}{50}$ & $\stackrel{\Xi}{E}$ & $\underset{\mathscr{D}}{\stackrel{0}{0}+}+$ \\
\hline Helmet prevents head injury & 8.3 & 54.2 & 8.3 & 20.0 & 9.2 & 100 & & 3.32 \\
\hline $\begin{array}{l}\text { Government should continue } \\
\text { to enforce helmet usage }\end{array}$ & 8.3 & 30.8 & 0 & 49.2 & 11.7 & 100 & & 2.74 \\
\hline $\begin{array}{l}\text { Helmet should always be used } \\
\text { while riding }\end{array}$ & 0 & 37.5 & 0 & 38.3 & 24.2 & 100 & & 2.50 \\
\hline $\begin{array}{l}\text { Helmet must always be } \\
\text { correctly buckled when worn }\end{array}$ & 12.5 & 14.2 & & 54.2 & 19.1 & 100 & & 2.47 \\
\hline $\begin{array}{l}\text { Non-usage of helmet should } \\
\text { attract greater penalty }\end{array}$ & 0 & 0 & 0 & 62.5 & 37.5 & 100 & & 1.62 \\
\hline Helmet usage is important & 36.6 & 35.8 & 0 & 27.5 & 0 & 100 & & 3.81 \\
\hline $\begin{array}{l}\text { Total } \\
\text { (Average \%) }\end{array}$ & 11.0 & 28.8 & 1.4 & 41.9 & 16.9 & 100 & & 2.75 \\
\hline
\end{tabular}

Note: Strongly agreed (5), Agreed (4), I don’t know (3), Disagree (2) Strongly disagree (1)

++ Maximum mean score $=5.0$

Furthermore, as seen in table 4 only $12.5 \%$ of the operators strongly agreed that helmet should always be properly buckled when used while $73.3 \%$ are in disagreement with this idea. In addition, a large majority (72.4\%) of the riders accept that the usage of crash helmet is important. These results indicate that the riders are largely aware of the important protection crash helmets could provide in case of accident but most of them are just averse to its use. For instance, the high 
mean scores of 3.81 and 3.32 for 'helmet usage is important' and 'helmet prevents head injury' respectively, is a clear indication that the respondents are aware of the significance of the protective role of crash helmets. However, this antipathy for helmet use may be the result of the general low compliance with road safety regulations by road users, particularly commercial motorcyclists in Nigeria (Adisa, 2010; Johnson and Adebayo, 2011; Tunde et al., 2012; Olusayo et al., 2015; Oyelade et al., 2015). Furthermore, reluctance to properly buckle helmet while in use is also an indication of aversion to the use of helmet by the riders, which greatly reduces the effectiveness of crash helmet in case of accident. When not properly buckled there is much likelihood that the helmet will fall off during a crash thereby exposing the rider's head to injury.

\section{CONCLUSION}

Conclusively, this study has shown that the rate of use of helmet among commercial motorcyclist is low in Ilorin. This is a further confirmation of the poor level of adherence to the helmet law in Nigeria. Reluctance of commercial motorcyclist to use helmet even when it is known to be beneficial, in conjunction with poor level of enforcement have continued to be responsible for low level of compliance with the helmet law in Nigeria.

It is therefore recommended that greater efforts should be directed towards public enlightenment on the importance of helmet usage particularly its role in preventing head injury in case of accident. Agencies such as the Federal Road Safety Commission (FRSC), the National Orientation Agency (NOA), Ministries of Health at federal and state levels and None Governmental Agencies (NGOs) in conjunction with the riders' associations should be fully involved in this effort.

Furthermore, there is the need for proper enforcement of the helmet law. The law should be fully implemented to ensure that all riders wear crash helmets at all the times, when operating motorcycles. Appropriate punishments including fines and even imprisonment should also be applied to ensure enforcement. This could be made more effective through the use of mobile courts for quick dispensation of justice.

In addition, appropriate mechanisms should be put in place for a gradual phasing out of the use of motorcycles for commercial transport services particularly in urban areas. If mass transit services could not be adequately introduced, motorcycles should be replaced with tricycles which are comparatively safer while also providing services in areas not easily served by four wheeled vehicles.

\section{REFERENCES}

Ackaah, W., \& Afukaar, F. K. (2010). Prevalence of helmet use among motorcycle users in Tamale Metropolis, Ghana: an observational study. Traffic injury prevention, 11(5), 522-525.

Adefalu, L. L., Bale, I. O., \& Musa, M. O. (2013). Analysis of Youths Involvement in Non-Farm Activities in Selected Rural Communities of Kwara State, Nigeria. The Zaria Geographer, 20 (1), 75-84.

Adisa, R. S. (2010). A study of the use of intoxicants among rural commercial motorcyclists in Kwara State, Nigeria. Journal of Social Sciences, 22(2), 85-91.

Blueprint Newspapers Online (2014). Okada and Nigeria's transport system. November 4, 2014.

Branas, C. C., \& Knudson, M. M. (2001). Helmet laws and motorcycle rider death rates. Accident Analysis \& Prevention, 33(5), 641-648.

Dandona, R., Kumar, G. A., \& Dandona, L. (2006). Risky behavior of drivers of motorized two wheeled vehicles in India. Journal of safety research, 37(2), 149-158.

Department of Environment, Transport and the Region (DETR) (2000). Tomorrows' Roads - Safer for Everyone: The Governments' Road Safety Strategy and Casualty Reduction Target for 2010. London: HMSO.

Falope, I. A. (1991). Motorcycle accidents in Nigeria. A new group at risk. West African journal of medicine, 10(2), 187-189.

Gbadamosi, K. T. (2006). The emergence of motorcycle in urban transportation in Nigeria and its implication on traffic safety. Association for European Transport and contributors, 16.

Global Road Safety Partnership (2014). Vulnerable Road Users, www.grsproadsafety.org/our-knowledge/safer-roadusers/vulnerable-road-users, accessed at 17.02.2015. https://theeagleonline.com.ng/fg-opposes-ban-of-mtorcyclestricycles-for-commercial-transportation/, accessed at 06.04.2018

https://www.blueprint.ng/okada-and-nigerias-transport-system/, accessed at 11.09.2017 
Hung, D. V., Stevenson, M. R., \& Ivers, R. Q. (2006). Prevalence of helmet use among motorcycle riders in Vietnam. Injury prevention, 12(6), 409-413.

Ilorin.Info (2017). FRCS, Okada riders differ on commercial motorcycle ban in Kwara, https://www.ilorin.info/fullnews.php?id=20284 Accessed at 19.12.2017

Independent National Electoral Commission (INEC) (2010). Kwara State: A Directory of Polling Units 2010. Abuja: INEC.

Iweze, D. O. (2011). Travails on the Nigerian Roads: The Case of the Luxury Bus Transport Services. In $4^{\text {th }}$ European Conference on African Studies. Uppsala, Sweden.

Johnson, O. E., \& Adebayo, A. M. (2011). Effect of Safety Education on Knowledge of and Compliance with Road Sefety Signs Among Commercial Motorcyclists in Uyo, Southern Nigeria. Ghana medical journal, 45(3), 89-96.

Kwara State Government (1997). Diary, 1997. Ilorin: Kwara State Ministry of Information.

National Bureau of Statistics (2018). Key Statistics: Unemployment, http://www.nigerianstat.gov.ng/, accessed at 07.09.2018

National Highway Traffic Safety Administration (NHTSA) (2012). Helmet Effectiveness Revisited. Washington, DC: US Department of Transportation.

Oboh, M. (2009). Nigerian bikers wear fruit shells to avoid helmet laws. Reuters, January 7, 2009. https://www.reuters.com/article/us-nigeria-bikers/nigerian-bikers-wear-fruit-shells-to-avoid-helmetawidUSTRE5063FR20090107, accessed at 03.01.2018

Ogunrinola, I. O. (2011). Informal self-employment and poverty alleviation: empirical evidence from motorcycle taxi riders in Nigeria. International journal of economics and finance, 3(2), 176-185.

Olakulehin, O. A., Adeomi, A. A., Oakanbi, O., Itie, C. J., Olanipekun, O. O., \& Silori, O. (2015). Perception and Practice of Helmet Use among Motorcycle Riders in a Semi-Urban Community in Southwestern Nigeria. IOSR Journal of Dental and Medical Sciences (IOSR-JDMS), 14(2), 120 - 124.

Olubomehin, O. O. (2012). The development and impact of motorcycles as means of commercial transportation in Nigeria. Research on Humanities and Social Sciences, 2(6), 231- 239.

Olusayo, A. I., Oyetunde, O. B., Okeibunor, O. L., Adedokun, O. S., \& Adedeji, A. S. (2015). Road traffic injury immune delusion syndrome among commercial motorcycle riders in Ogbomoso, Nigeria. Global Advance Research Journal of Medicine and Medical Science, 4(2), 092-097.

Oni, S. I., Fashina, O., \& Olagunju, Y. K. (2011). The motorcycle crash characteristics in Lagos State, Nigeria. Journal of Environmental Management and Safety, 2(1), 1-15.

Oyelade, B. O., Amole, I. O., Odeigah, L. O., Aderibigbe, S. A., \& Oladeji, S. (2015). The Use of Crash Helmets among Commercial Motorcycle Riders in Ogbomoso, South-West, Nigeria. Merit Research Journal of Medicine and Medical Sciences, 3(2): 62-68.

Oyelade, B. O., Amole, I. O., Odeigah, L. O., Aderibigbe, S. A., \& Oladeji, S. (2015). The Use of Crash Helmets among Commercial Motorcycle Riders in Ogbomoso, South-West, Nigeria. Merit Research Journal of Medicine and Medical Sciences, 3(2): 62-68. http://www.meritresearchjournals.org/mms/index.htm, accessed at 17.11.2017

Solagberu, B. A., Ofoegbu, C. K. P., Nasir, A. A., Ogundipe, O. K., Adekanye, A. O., \& Abdur-Rahman, L. O. (2006). Motorcycle injuries in a developing country and the vulnerability of riders, passengers, and pedestrians. Injury prevention, 12(4), 266-268.

Swaddiwudhipong, W., Boonmak, C., Nguntra, P., \& Mahasakpan, P. (1998). Effect of motorcycle rider education on changes in risk behaviours and motorcycle-related injuries in rural Thailand. Tropical medicine \& international health, 3(10), 767-770.

The Eagle Online (2017). FG Opposes Ban of Motorcycles, Tricycles For Commercial Transportation. March 1, 2017.

Tunde, A. G., Taiwo, O. A., \& Matanmi, O. G. (2012). Compliance with Road Safety Regulations Among Commercial Motorcyclists in Nigeria/Conformite a la Reglementation de la Securite Routiere Parmi Les Motocyclistes Au Nigeria. Canadian Social Science, 8(1), $92-100$.

Usman, B. A., \& Akniola, O. (2018). Gender Differentials in Transportation Characteristics of Students of Tertiary Education Institutions in Ilorin, Nigeria. Ife Research Publications in Geography, 15(1), 91-106.

World Health Organization (2006). Helmets: A Road Safety Manual for Decision-makers and Practitioners. WHO: Geneva, Switzerland.

World Health Organization (WHO) (2006). Helmets: A Road Safety Manual for Decision-makers and Practitioners. WHO: Geneva, Switzerland.

Yusuf, A. S., Odebode, T. O., Adeniran, J. O., Salaudeen, A. G., Adeleke, N. A., \& Alimi, M. F. (2014). Pattern and outcome of motorcyclists head injury in Ilorin, Nigeria. Nigerian Journal of Basic and Clinical Sciences, 11(2), 80 - 84

Submitted:

February 02, 2019
Revised:

August 12, 2019
Accepted and published online September 18, 2019 